This item was submitted to Loughborough's Research Repository by the author.

Items in Figshare are protected by copyright, with all rights reserved, unless otherwise indicated.

\title{
Immunological aspects of sport nutrition
}

PLEASE CITE THE PUBLISHED VERSION

http://dx.doi.org/10.1038/icb.2015.109

PUBLISHER

Nature Publishing Group

VERSION

AM (Accepted Manuscript)

PUBLISHER STATEMENT

This work is made available according to the conditions of the Creative Commons Attribution-NonCommercialNoDerivatives 4.0 International (CC BY-NC-ND 4.0) licence. Full details of this licence are available at: https://creativecommons.org/licenses/by-nc-nd/4.0/

\section{LICENCE}

CC BY-NC-ND 4.0

\section{REPOSITORY RECORD}

Gleeson, Michael. 2019. "Immunological Aspects of Sport Nutrition". figshare. https://hdl.handle.net/2134/20675. 
Immunol Cell Biol. 2015 Dec 4. doi: 10.1038/icb.2015.109. [Epub ahead of print] PMID: 26634839

\section{Immunological Aspects of Sport Nutrition}

\section{Michael Gleeson BSc PhD}

School of Sport, Exercise and Health Sciences, Loughborough University, Loughborough LE11 3TU, UK

Address for correspondence:

Professor Michael Gleeson

School of Sport, Exercise and Health Sciences

Loughborough University

Ashby Road

Loughborough

Leicestershire

LE11 3TU

UK

Tel. +44(0)1509 226345

Email: m.gleeson@lboro.ac.uk

\section{Conflicts of interest}

The author has receiving funding for research from GlaxoSmithKline, Nestle, PepsiCo and Yakult.

\section{Abstract}

Prolonged bouts of exercise and heavy training regimens are associated with depression of immune system functions which can increase the risk of picking up opportunistic infections such as the common cold and influenza. Some common sport nutrition practices including high carbohydrate diets and carbohydrate ingestion during exercise, training with low glycogen stores, intentional dieting for weight loss, ingestion of high dose antioxidant supplements and protein ingestion post-exercise may influence immune system status in athletes. In order to maintain robust immunity, athletes need to consume a well-balanced diet that is sufficient to meet their requirements for energy, carbohydrate, protein, and micronutrients. Dietary deficiencies of protein and specific micronutrients are well known to be potential causes of immune dysfunction and an adequate intake of some essential minerals including iron and zinc and the vitamins A, D, E, B6 and B12 are important to maintain a healthy immune function. Vitamin $D$ may be a particular concern as recent studies have emphasised its importance in limiting infection episode incidence and duration in both the general population and in athletes and many individuals exhibit inadequate vitamin $D$ status during the winter months. There is only limited evidence that individual amino acids, $\beta$-glucans, herbal extracts and zinc are capable of boosting immunity or reducing infection risk in athletes. The ingestion of carbohydrate during exercise and daily consumption of probiotics, vitamin D3, bovine colostrum, and plant polyphenol containing supplements or foodstuffs currently offer the best chance of success, particularly for those individuals who are prone to illness. 


\section{Introduction}

Athletes who engage in intense training or who have recently competed in endurance race events appear to be at increased risk of developing symptoms of minor upper respiratory illness symptoms (URS) ${ }^{1-5}$. The most common illnesses in athletes are viral infections of the upper respiratory tract (i.e. the common cold), but athletes can also develop similar symptoms (e.g. sore throat) due to allergy or inflammation caused by inhalation of cold, dry or polluted air ${ }^{6}$. In themselves, these URS have generally trivial consequences, but importantly to the elite athlete they can disrupt training, cause under-performance or even require withdrawal from competition. Prolonged bouts of vigorous exercise have been shown to result in transient depression of several white blood cell (leukocyte) functions and it is suggested that such changes create an "open window" of diminished host protection, during which viruses and bacteria can gain a foothold, increasing the risk that infection symptoms will develop ${ }^{5}$. Other factors such as competition ${ }^{3,4}$ and psychological stress, lack of sleep $^{7}$, exposure to environmental extremes (e.g. altitude) and malnutrition can also depress immunity ${ }^{8,9}$ and lead to increased risk of infection (Figure 1). There are also some situations in which an athlete's exposure to infectious agents may be increased - this is the other important determinant of infection risk. During exercise, because lung ventilation rates are increased there is increased exposure of the airways to airborne bacteria and viruses. An increase in gut barrier permeability may also allow entry of gut bacterial endotoxins into the circulation, particularly during prolonged exertion in the heat ${ }^{10}$. In contact sports, skin abrasions may occur increasing the risk of transdermal infections. In some sports, the competitors may be in close proximity to large crowds. Air travel to foreign countries may be required and this is known to increase infection risk in athletes ${ }^{3}$. Hence, the cause of the increased incidence of URS in athletes is most likely multifactorial (Figure 1). A variety of stressors, not only physical but also psychological, environmental, and nutritional may combine to suppress immune function, and these effects, together with increased exposure to potentially disease-causing pathogens, make the athlete more susceptible to infection; secondly, URS may arise from inflammatory stimuli that result in noninfectious irritation of the upper airways.

\section{Maintaining an effective immune system}

A varied diet with appropriate intakes of energy, protein, vitamins and minerals are essential to maintain the body's natural defences against disease causing viruses and bacteria. Athletes should generally consume a diet that meets their energy needs and contains all the essential nutrients in adequate amounts in order to maintain an effective immune system ${ }^{9}$. Dietary deficiencies of protein, energy and particular micronutrients (e.g. the minerals copper, iron, manganese, magnesium, selenium and zinc, and vitamins A, C, D, E, B6, B12 and folic acid), must be avoided as these will decrease immunity against viral and bacterial pathogens and make the individual more susceptible to infection ${ }^{8}$. Even short-term dieting in athletes who continue to train hard that results in a loss of a few kilograms body mass over the course of a few weeks can result in significant falls in several aspects of immune function ${ }^{11,12}$. Thus, care should be taken to ensure intakes of protein and essential micronutrients are adequate during periods of intentional weight loss. In general, a broad-range multivitamin/mineral supplement is the best choice to support a restricted food intake, and this may also be suitable for the travelling athlete in situations where food choices and quality may be limited. Vitamin $D$ is now recognised to play an important role in up-regulating immunity ${ }^{13}$ and this is a concern as Vitamin D insufficiency is common in athletes ${ }^{14,15}$ especially if exposure to natural sunlight is limited (e.g. when training in the winter months or when training mostly 
indoors). In recent years some studies in both athletes ${ }^{16}$ and the general population ${ }^{17}$ have provided evidence that sufficient vitamin $D$ status optimizes immune function and helps defend against the common cold. Hence, athletes who are deficient or insufficient in vitamin $D$ (this can be established with a blood test to measure the circulating concentration of 25-hydroxy-vitamin D) are likely to benefit from vitamin $D$ supplementation. Athletes should also be warned that binge drinking of alcohol depresses immune function for several hours ${ }^{18}$ and this practice should be avoided, particularly after heavy training sessions or competition.

\section{Nutritional strategies that may help to limit exercise-induced immune depression}

Certain dietary supplements may boost immune function and reduce infection risk in individuals who are subjected to stress ${ }^{1,9}$. While there are many nutritional supplements that are claimed to boost immunity (Table 1), such claims are often based on very limited and often selective evidence of efficacy in animals, in vitro experiments, children, the elderly or clinical patients in severe catabolic states and direct evidence for their efficacy for boosting immunity or limiting exercise-induced immune depression in athletes is usually lacking. The bulk of this short review focuses on describing the limited number of nutritional strategies and supplements for which there is some supportive scientific evidence base for efficacy in reducing immune perturbations during exercise and/or in decreasing infection incidence.

\section{Carbohydrate beverages}

Carbohydrate ingestion during exercise limits metabolic stress by helping to maintain the blood glucose concentration. The use of a high-carbohydrate diet and carbohydrate ingestion (about 30-60 g/h) during prolonged workouts lowers circulating stress hormone (e.g. adrenaline and cortisol) and anti-inflammatory cytokine (e.g. interleukins 6 and 10) responses to exercise and delays the appearance of symptoms of overreaching during intensive training periods ${ }^{19}$. This reduces the impact of prolonged exercise on several, but certainly not all, aspects of immune function and there is currently a lack of evidence to support the hypothesis that this translates to a reduced incidence of URS following competitive events. When training sessions are performed in a fasting or low-glycogen state and without carbohydrate ingestion during exercise it is likely that a more substantial degree of immune depression will develop (especially if this is not the first training session of the day). If this train-low (glycogen) concept is to be applied to maximise training adaptation $^{20}$ it should not be done for more than a few days per week or immune function will be compromised.

The consumption of beverages during exercise helps to prevent dehydration (which is elevated stress hormone responses) and maintains saliva flow rate during exercise. Saliva contains several antimicrobial proteins including immunoglobulin A $(\lg A)$, lysozyme, $\alpha$-amylase, lactoferrin and defensins. Saliva secretion usually falls during exercise and in combination with dehydration has been shown to decrease the secretion rates of several of these antimicrobial proteins ${ }^{21}$ but regular fluid intake during exercise can prevent this.

\section{Post-exercise protein ingestion}

Regular ingestion of $\sim 20 \mathrm{~g}$ protein in meals throughout the day and ingestion of protein after training sessions and before bedtime is now recognised as an effective strategy to promote muscle recovery from damage and training adaptation, particularly with regard to muscle hypertrophy in response to resistance training 
regimens ${ }^{22}$. An adequate protein intake is certainly required to maintain normal immune function ${ }^{8}$ and there is some evidence that ingesting protein after prolonged exercise can attenuate some aspects of post-exercise immune depression ${ }^{23,24}$ and reduce respiratory infection incidence in overreaching athletes ${ }^{23}$.

\section{Antioxidant vitamins}

It is not known whether hard training increases the need for dietary antioxidants since the body naturally develops an effective defence with a balanced diet and endogenous antioxidant defences actually improve as an adaptation to endurance exercise training. However, there is some evidence to suggest that regular intake of relatively high doses of antioxidant vitamins can reduce the cortisol and antiinflammatory cytokine response to prolonged exercise ${ }^{25,26}$. These studies have used combinations of vitamin $\mathrm{C}$ and $\mathrm{E}$, or vitamin $\mathrm{C}$ alone, at doses several fold higher than the recommended dietary allowances, and provide a possible mechanism to explain earlier findings of a benefit of vitamin $C$ supplementation in reducing the incidence of respiratory illness symptoms in individuals who took part in ultramarathon races ${ }^{27}$. The most recent Cochrane meta-analysis examined the evidence that daily doses of more than $200 \mathrm{mg}$ vitamin $\mathrm{C}$ were more effective in preventing or treating the common cold than placebo ${ }^{28}$. Twenty-nine trial comparisons involving 11077 study participants contributed to this meta-analysis on the relative risk $(\mathrm{RR})$ of developing a cold while taking prophylactic vitamin $\mathrm{C}$. The pooled RR was $0.96(95 \% \mathrm{Cl} 0.92$ to 1.00$)$. A subgroup of six trials that involved a total of 642 highly physically active subjects (including marathon runners, skiers, and military personnel) reported a pooled RR of $0.50(95 \% \mathrm{Cl} 0.38$ to 0.66$)$. Thirty comparisons that involved 9676 respiratory episodes contributed to the metaanalysis on the duration of common cold episodes with vitamin $C$ versus placebo supplementation and revealed that in adult participants cold episode duration was reduced by $8 \%(95 \% \mathrm{Cl} 3 \%$ to 13\%). Fifteen trial comparisons that involved 7045 respiratory episodes contributed to the meta-analysis of severity of episodes and the results indicated a benefit of vitamin $\mathrm{C}$ in reducing the number of days confined to home and off work or school. The failure of vitamin $\mathrm{C}$ supplementation to reduce the incidence of colds in the normal population is indicates that routine ingestion of mega-doses of vitamin $C$ is not generally justified but that individuals who are engaged in repeated bouts of vigorous physical exercise may well gain some benefit.

However, some concerns have been expressed about the potential negative effects on training adaptation of regularly ingesting high-dose antioxidant supplements ${ }^{29}$, though whether or not this is likely to affect adaptations in already well-trained athletes performing intensive training has been questioned ${ }^{30}$. There is little evidence of any immune benefit from excessive supplementation with other antioxidant vitamins so this cannot be recommended. Indeed, over-supplementation can diminish the body's natural antioxidant defence system and so probably the wisest option is ensure that the diet contains plenty of fresh fruits and vegetables.

\section{Vitamin D3 supplements}

The discovery of a vitamin $D$ receptor in cells of the immune system, including $T$ and $B$ lymphocytes, neutrophils and antigen presenting cells has prompted the idea that vitamin $D$ could have a vital role in the regulation of immune responses ${ }^{13}$, suggesting a more global role for vitamin $D$ than its long established effects on calcium transport and bone health. Unlike the other vitamins that are obtained through the diet, vitamin $D$ is unique since it is mostly produced via endogenous synthesis from a cholesterol precursor (7-dehydrocholesteol) in the skin following sunlight (ultraviolet B radiation) 
exposure with usually less than $20 \%$ of the body's needs coming from the diet. Although controversy exists over what represents optimal vitamin D status, there is accumulating evidence to suggest that many athletes are vitamin D deficient ${ }^{15,16}$, especially in the winter months, largely as a consequence of inadequate sun exposure, combined with poor dietary practices. The health and performance consequences of such deficiencies are still somewhat unclear in athletic populations but some studies have reported impaired muscle function, reduced regenerative capacity and increased bone fracture risk ${ }^{15}$, together with impaired immune function and increased respiratory infection risk ${ }^{16}$ with low Vitamin D status in athletes. Vitamin $D$ is important in inducing production of antimicrobial proteins, upregulating genes for junction proteins in epithelial cells, enhancing NK cell cytolytic activity, increasing the generation of reactive oxygen species and the expression of inducible nitric oxide synthase in phagocytic cells as well as augmenting interleukin-1 $\beta$ secretion and upregulating the expression of CD14, the lipopolysaccharide receptor. Low vitamin D status in athletes low vitamin D status is associated with low saliva $\lg A$ secretion, low pro-inflammatory cytokine production by antigen-stimulated blood mononuclear cells and increased respiratory infection risk with longer lasting illness symptoms ${ }^{16}$. Oral vitamin D3 supplements of around $4000 \mathrm{IU}$ per day can elevate vitamin $D$ status from deficient levels to adequate or high levels within a matter of weeks and can significantly elevate saliva $\lg A$ and defensin secretion rates in athletes $^{31}$. Oral vitamin D3 supplements of around $1000 \mathrm{IU}$ per day can maintain adequate vitamin $D$ status throughout the winter months if status is adequate at the end of summer. Several large scale studies in the general population indicate that vitamin D3 supplements reduce the number of common cold episodes and reduce the use of antibiotics ${ }^{17}$ so there is a likely benefit for athletes who have low vitamin D status.

\section{Other Supplements to Support Immunity for Athletes}

Various other nutritional supplements have been tested for their capacity to either boost immunity or limit the immune disturbance following prolonged strenuous exercise and thus lower infection risk. This strategy is similar to the nutritional strategies that are provided to patients recovering from trauma and surgery, and to the frail elderly. Supplements studied thus far in human athletes include herbal extracts (e.g. Echinacea), plant sterols, polyphenols (e.g. quercetin) and polysaccharides (e.g. $\beta$-glucans), omega-3 polyunsaturated fatty acids, glutamine, branched-chain amino acids, bovine colostrum and zinc. Although some supplements (e.g. zinc $^{32}$ and some herbals such as Kaloba ${ }^{33}$ ) may reduce the duration or severity of illness episodes if taken close to the onset of symptoms, generally the results have been disappointing with regard to reducing infection incidence (see Table 1). However, there is emerging evidence that probiotics, colostrum and plant polyphenols may provide some protective benefit against infection.

\section{Plant polyphenols}

Plant polyphenols, which include a class of compounds called flavonoids, are potent antioxidant compounds. Several of these compounds are of great current interest due to their antioxidant, anti-inflammatory, anti-pathogenic, cardio-protective, and anti-carcinogenic activities. One of them, quercetin, is a phytonutrient found in variety of fruits and vegetables and has received considerable attention in recent years in relation to its possible effects on exercise performance, training adaptation and immune function. Animal studies indicate that ingesting quercetin for 7 days improves survival from influenza virus innoculation. A human study ${ }^{34}$ showed that $1000 \mathrm{mg}$ of 
a quercetin supplement, ingested daily for 3 weeks, reduced URS during the 2 weeks following a 3-day period of exhaustive exercise in cyclists. None of the measured markers of Immune dysfunction, inflammation, and oxidative stress, however, were altered in this study and the authors concluded that quercetin may have exerted direct anti-viral effects. Another study reported a lower incidence of URS among physically active middle-aged people with daily quercetin supplementation ${ }^{35}$ but larger scale, double blind, placebo controlled studies are needed to confirm an effect of quercetin in reducing infection incidence in athletes who are training hard.

Naturally occurring polyphenolic compounds are present in foods such as apples, pears, citrus fruits, red grapes, green leafy vegetables and onions, as well as some plant-based beverages such as citrus juices, green tea, beer and red wine. A large scale study in physical active individuals indicated that a high fruit intake was associated with fewer respiratory illness episodes ${ }^{36}$. The bulk of a diet containing a large amount of fruit and vegetables can be a problem for athletes who need to ingest relatively large amounts of carbohydrate (and protein) to meet their energy requirements and an alternative solution to ensure a high polyphenol intake is to ingest commercially available fruit extract concentrates in the form of powders, tablets or capsules. A recent study reported that regular ingestion of non-alcoholic beer (NAB) polyphenols prior to and after a marathon reduced the incidence of respiratory illness symptoms in the 2 weeks following the race by 3.25 fold $^{37}$. In this study 277 middle-aged male runners were randomly assigned to drink 1-1.5 litres per day of a NAB or placebo (PLA) beverage for 3 weeks before and for 2 weeks after the marathon. Following the race blood markers of inflammation and oxidative stress were lower with NAB. Another recent study that examined the effects of regular ingestion of dark chocolate (cocoa is another source of polyphenols) prior to an exhausting bout of cycling reported reduced oxidative stress markers but no effects on immunoendocrine responses to the exercise ${ }^{38}$ so the type and dose of polyphenols may be important.

\section{Probiotics}

In recent years several studies have examined the efficacy of oral probiotics for reducing URS incidence in athletes and some probiotic supplements, particularly those containing Lactobacillus strains, have shown some promise. Often called the friendly bacteria, probiotics are defined as 'Live microorganisms that, when administered in adequate amounts, confer a health benefit on the host'. Therefore, the term 'probiotic' should only apply to products containing a suitable number of live cells of well-defined and safe microbial strains, and with a reasonable level of scientific evidence of health benefit from a body of research that included well conducted human studies. Probiotic actions include modification of the bacterial population (microbiota) that inhabits our gut and modulation of immune function by their interaction with the gut-associated lymphoid tissue, leading to positive effects on the systemic immune system. There are now several well-controlled studies in athletes that have indicated that daily probiotic ingestion results in fewer days of respiratory illness and lower severity of URS ${ }^{39-45}$ and a recent meta-analysis using data from both athlete and non-athlete studies involving 3451 subjects concluded that there is a likely benefit in reducing URS incidence ${ }^{46}$. Thus, probiotic supplements may reduce URS incidence as well as reducing gastrointestinal discomfort problems (a common complaint of endurance runners). Another potential benefit of probiotics could be a reduced risk of gastrointestinal infections - a particular concern when travelling abroad. Further large-scale studies are needed to confirm that taking probiotics can reduce the number of training days lost to infection and to determine the most effective probiotics as their effects are strain-specific. The studies to date 
that have shown reduced URS incidence in athletes have been mostly limited to Lactobacillus and Bifidobacterium species and have used daily doses of $\sim 10^{10}$ live bacteria. Given that some probiotics appear to provide some benefit, with no evidence of harm and are low cost, there is no reason why athletes should not take probiotics, especially if travelling abroad or illness-prone. It is worth noting that there is accumulating evidence that the diversity of the gut microbiota is influenced by diet, exercise and environmental factors ${ }^{47}$ as well as probiotics and some pathologies and, although not well understood at present, this may have health implications for athletes.

\section{Colostrum}

Bovine colostrum is a thick creamy-yellow liquid, produced by the mammary gland of a lactating cow shortly after birth of her calf, usually within the first $36 \mathrm{~h}$. Colostrum contains a cocktail of antibodies, enzymes, glycosphingolipids, growth factors, minerals and vitamins and is commercially available in both liquid and powder forms. Numerous health claims have been made for colostrum ranging from performance enhancement to preventing infections, but well-controlled studies in athletes are rare. The glycosphingolipids (gangliosides) in colostrum may modify the gut microbial flora and act as decoy targets for bacterial adhesion as well as having some direct actions on immune cell functions. A few studies suggest that several weeks of bovine colostrum supplementation can elevate levels of antibodies in the circulation and saliva, prevent exercise-induced falls in salivary lysozyme and speed the recovery of neutrophil function after strenuous exercise ${ }^{48,49}$. Regular ingestion of bovine colostrum may also limit the increase in gut permeability caused by prolonged strenuous exercise and reduce the risk of developing heat stroke ${ }^{50}$. Several studies have also reported that daily oral bovine colostrum supplementation reduces the total number of days with self-reported URS ${ }^{48,51-53}$, the incidence of URS episodes ${ }^{48,51-54}$ and duration of self-reported URS episodes ${ }^{51,53}$ in adults involved in exercise training.

\section{$\beta$-glucans}

$\beta$-glucans are structural polysaccharides that are present in the cell walls of yeast, fungi and some bacteria and as part the endosperm cell wall in cereals, such as barley and oat. The specific characteristics of the various $\beta$-glucans may influence their immune modulating effects: it appears that high molecular weight and/or particulate $\beta$-glucans from fungi directly activate leukocytes, whereas low molecular weight $\beta$-glucans from fungi only modulate the response of immune cells when they are stimulated with antigens or cytokines ${ }^{55}$. To date there is limited evidence for immune-promoting effects of orally administered oat $\beta$-glucans in humans but several animal studies have provided evidence of enhanced resistance to bacterial and parasitic infections ${ }^{56}$. Furthermore, daily ingestion of oat $\beta$-glucan counteracted the decrease in macrophage antiviral resistance induced by exercise stress in mice ${ }^{57}$. One trial in humans found no effect of 3 weeks of oat $\beta$-glucan supplementation on immune responses to exercise or infection incidence during the 2-week period following 3 successive days of exhaustive exercise ${ }^{58}$. More recently, however, another human study reported a $37 \%$ reduction in the number of URS days following a marathon with yeast $\beta$-glucan supplementation versus placebo which the authors attributed to a post-exercise increase in salivary $\lg A^{59}$.

\section{Summary}

In conclusion, it is difficult to make firm judgments about which nutritional supplements are really effective in boosting immunity or reducing infection risk in athletes. It is safe to say with reasonable confidence that individual amino acids, 
Echinacea, vitamin $\mathrm{E}$ and zinc are unlikely to be of significant clinical benefit. Current recommendations for immuno-nutrition support in athletes include:-

- Overall daily energy intake should match energy needs with $>50 \%$ coming from carbohydrate

- Ingest 30-60 g of carbohydrate per hour during strenuous training sessions

- Ingest of adequate amounts of protein (1.2-1.6 g/kg/day) which should include ingestion of $0.3 \mathrm{~g} / \mathrm{kg}$ in meals following training sessions

- Ingest adequate amounts of micronutrients (this can be ensured by taking a daily multi-vitamin/mineral tablet that meets the RDAs

- Take a daily oral vitamin D3 supplement of $1000 \mathrm{IU}$ at the start of autumn until early spring

- Take a daily probiotic supplement containing at least $10^{10}$ live bacteria

- Include a variety of fruit and vegetables as part of the normal diet (at least on 5 days per week); this can be supplemented with plant polyphenol supplements or beverages (e.g. green tea, non-alcoholic beer) or concentrated fruit/vegetable extracts

- Consider taking a daily 10-20 g bovine colostrum powder supplement

- Consider taking zinc and Kaloba supplements in the days leading up to an important competition in case cold symptoms should begin at that important time

This approach is likely to be of most benefit to those individuals who are particularly prone to illness. It is important to remember that nutrition is only one factor with regard to infection risk and there are several other strategies listed below that can minimise the risk of developing immune function depression or reduce the degree of exposure to pathogens and thus limit infection risk:

Minimise the chances of developing immunodepression:-

- Avoid very prolonged training sessions (>2 h), overtraining and chronic fatigue

- Keep other life stresses to a minimum

- Get adequate sleep quantity (at least $7 \mathrm{~h}$ ) and quality

- Avoid rapid weight loss

- Avoid binge drinking of alcohol

- Vaccinate against influenza if competing in the winter

Minimise the potential for transmission of infectious agents:-

- Avoid sick people and large crowds in enclosed spaces if possible

- Good personal skin and oral hygiene (wash hands and use antimicrobial gels on hands; brush teeth regularly and use an antibacterial mouth rinse)

- Never share drink bottles, cutlery, towels etc

- Avoid putting hands to eyes and nose (a major route of viral selfinoculation)

\section{Future research directions}

In vitro cell culture and animal research indicate that some supplements such as $\beta$ glucans, curcumin, quercetin, isoquercetin, catechins and other plant polyphenols or unique plant extracts warrant further human investigations to determine if they are effective countermeasures to exercise-induced immune dysfunction and risk of URS. A combination of these will probably perform better than any single supplement alone and Nieman ${ }^{60}$ has suggested that most benefit is likely to accrue from supplements that primarily target the nonspecific, innate arm of the immune system to enhance immunosurveillance against a wide variety of pathogens. Further studies are also 
needed to determine the most effective probiotics as their effects are both species and strain specific. More research is also needed on the interactions between diet, exercise and the gut microbiota in relation to athlete health. A general weakness of many previous immuno-supplement studies is that they have been low powered and have, with a few exceptions, used only short (days or weeks) periods of intervention. What is really needed are larger scale, longer-term, well conducted (i.e. randomized, double-blinded, placebo-controlled) studies of the effects of nutritional supplements on URS incidence in athletes. Although various blood and salivary markers of immune function have been measured in human studies examining the mechanisms or efficacy of proposed immune-enhancing supplements, more appropriate markers are probably antibody titre response to influenza vaccination and URS symptom development following controlled nasal rhinovirus inoculation. Future studies of this nature should enable nutritionists to give more certain recommendations on how to best defend immunity in the face of the stresses imposed by athletic endeavour. 


\section{References}

1. Gleeson M, Bishop N, Walsh N (eds). Exercise Immunology. Routledge: London, UK, 2013.

2. Gleeson $M$, Williams $C$. Intense exercise training and immune function. In: van Loon LJC, Meeusen R (eds). Limits of Human Endurance, Nestle Nutrition Institute Workshop Series 2013, vol 76. Karger AG: Basel, Switzerland, 2013, pp $39-50$.

3. Svendsen IS. Factors influencing infection risk in endurance athletes. $P h D$ thesis 2015, Loughborough University, UK

4. Svendsen I, Gleeson M, Haugen T, Tønnessen E. Effect of an intense period of competition on race performance and self-reported illness in elite crosscountry skiers. Scand J Med Sci Sports 2015; e-pub ahead of print 27 March 2015; doi: 10.1111/sms.12452.

5. Walsh NP, Gleeson M, Shephard RJ, Gleeson M, Woods JA, Bishop NC et al. Position Statement Part One: Immune function and exercise. Exerc Immunol Rev 2011; 17: 6-63.

6. Bermon S. Airway inflammation and upper respiratory tract infection in athletes: is there a link? Exerc Immunol Rev 2007;13:6-14.

7. Cohen S, Doyle WJ, Alper CM, Janicki-Deverts D, Turner RB. Sleep habits and susceptibility to the common cold. Arch Intern Med 2009; 169: 62-67.

8. Calder PC, Yaqoob P (eds). Diet, Immunity and Inflammation. Woodhead Publishing: Cambridge, UK, 2014.

9. Walsh NP, Gleeson M, Pyne DB, Nieman DC, Dhabhar FS, Shephard RJ et al. Position Statement Part Two: Maintaining immune health. Exerc Immunol Rev 2011; 17: 64-103.

10. Lambert GP. Intestinal barrier dysfunction, endotoxemia, and gastrointestinal symptoms: the 'canary in the coal mine' during exercise-heat stress? Med Sport Sci 2008; 53: 61-73.

11. Shimizu K, Aizawa K, Suzuki N, Masuchi K, Okada H, Akimoto T et al. Influence of weight loss on monocytes and T-cell populations in male judo athletes. J Strength Cond Res 2011; 25: 1943-1950.

12. Umeda T, Nakaji S, Shimoyama T, Kojima A, Yamamoto Y, Sugawara K. Adverse effects of energy restriction on changes in immunoglobulins and complements during weight reduction in judo. J Sports Med Phys Fitness 2004; 44: 328-334.

13. Kamen DL, Tangpricha V. Vitamin $D$ and molecular actions on the immune system: modulation of innate and autoimmunity. J Mol Med 2010; 88: 441450. 
14. Larson-Meyer DE, Willis KS. Vitamin D and athletes. Curr Sports Med Rep 2010; 9: 220-226.

15. Owens DJ, Fraser WD, Close GL. Vitamin D and the athlete: emerging insights. Eur J Sport Sci 2015; 15: 73-84.

16. He CS, Handzlik M, Fraser WD, Muhamad A, Preston H, Richardson A et al. Influence of vitamin $D$ status on respiratory infection incidence and immune function during 4 months of winter training in endurance sport athletes. Exerc Immunol Rev 2013; 19: 86-101.

17. de Sa Del Fiol F, Barberatp-Filho S, Lopes LC, de Cassia Bergamaschi C. Vitamin D and respiratory infections. J Infect Dev Ctries 2015; 9: 355-361.

18. Afshar M, Richards S, Mann D, Cross A, Smith GB, Netzer G et al. Acute immunomodulatory effects of binge alcohol consumption. Alcohol 2015; 49: 57-64.

19. Halson SL, Lancaster GI, Achten J, Gleeson M, Jeukendrup AE. Effect of carbohydrate supplementation on performance and carbohydrate oxidation following intensified cycling training. J Appl Physiol 2004; 97: 1245-1253.

20. Hawley JA, Burke LM. Carbohydrate availability and training adaptation: effects on cell metabolism. Exerc Sport Sci Rev 2010; 38: 152-160.

21. Fortes MB, Diment BC, Di Felice U, Walsh NP. Dehydration decreases saliva antimicrobial proteins important for mucosal immunity. Appl Physiol Nutr Metab 2012; 37: 850-859.

22. Morton RW, McGlory C, Phillips S. Nutritional interventions to augment resistance training-induced skeletal muscle hypertrophy Front Physiol 2015; epub ahead of print 3 September 2015; doi:10.3389/fphys.2015.00245.

23. Witard OC, Turner JE, Jackman SR, Kies AK, Jeukendrup AE, Bosch JA et al. High dietary protein restores overreaching induced impairments in leukocyte trafficking and reduces the incidence of upper respiratory tract infection in elite cyclists. Brain Behav Immun 2014; 39: 211-219.

24. Papacosta-Kokkinou E, Nassis GP, Gleeson M. Effects of acute post-exercise chocolate milk consumption during intensive judo training on the recovery of salivary hormones, salivary $\operatorname{lgA}$, mood state, muscle soreness and judorelated performance. Appl Physiol Nutr Metab 2015; 40: 1116-1122.

25. Fischer CP, Hiscock NJ, Penkowa M, Basu S, Vessby B, Kallner A et al. Supplementation with vitamins $C$ and $E$ inhibits the release of interleukin- 6 from contracting human skeletal muscle. J Physiol 2004; 558: 633-645.

26. Davison G, Gleeson M. The effect of 2 weeks vitamin $C$ supplementation on immunoendocrine responses to $2.5 \mathrm{~h}$ cycling exercise in man. Eur J Appl Physiol 2006; 97: 454-461. 
27. Peters EM. Vitamins, immunity, and Infection risk in athletes. In: Nieman DC, Pedersen BK (eds). Nutrition and Exercise Immunology, CRC Press: Boca Raton, USA, 2000, pp 109-136.

28. Douglas RM, Hemila H, Chalker E, Treacy B. Vitamin $\mathrm{C}$ for preventing and treating the common cold. Cochrane Database Syst Rev 2007; 3: CD000980.

29. Ristow M, Zarse K, Oberbach A, Kloting N, Birringer M, Kiehntopf M et al. Antioxidants prevent health-promoting effects of physical exercise in humans. Proc Natl Acad Sci 2009; 106: 8665-8670.

30. Yfanti C, Akerström T, Nielsen S, Nielsen AR, Mounier R, Mortensen $\mathrm{OH}$ et al. Antioxidant supplementation does not alter endurance training adaptation. Med Sci Sports Exerc 2010; 42: 1388-1395.

31. He CS, Fraser WD, Tang J, Brown K, Renwick S, Rudland-Thomas J et al. The effect of 14 weeks of vitamin $D_{3}$ supplementation on antimicrobial peptides and proteins in athletes. J Sports Sci 2015; e-pub ahead of print April 2015; 10:1-8; PMID:25861808 (no doi for this journal).

32. Singh M, Das RR. Zinc for the common cold. Cochrane Database Syst Rev 2011; 2: CD001364.

33. Timmer A, Gunther J, Motschall E, Rücker G, Antes G, Kern WV. Pelargonium sidoides extract for treating acute respiratory tract infections. Cochrane Database Syst Rev 2013; 10: CD006323.

34. Nieman DC, Henson DA, Gross SJ, Jenkins DP, Davis JM, Murohy EA et al. Quercetin reduces illness but not immune perturbations after intensive exercise. Med Sci Sports Exerc 2007; 39: 1561-1569.

35. Heinz SA, Henson DA, Austin MD, Jin F, Nieman DC. Quercetin supplementation and upper respiratory tract infection: A randomized community clinical trial. Pharmacol Res 2010; 62: 237-242.

36. Nieman DC, Henson DA, Austin MD, Sha W. Upper respiratory tract infection is reduced in physically fit and active adults. Br J Sports Med 2011; 45: 987992.

37. Scherr J, Nieman DC, Schuster T, Habermann J, Rank M, Braun S et al. Nonalcoholic beer reduces inflammation and incidence of respiratory tract illness. Med Sci Sports Exerc 2012; 44: 18-26.

38. Allgrove JE, Farrell E, Gleeson M, Williamson G, Cooper K. Regular dark chocolate consumption's reduction of oxidative stress and increase of free-fattyacid mobilization in response to prolonged cycling. Int J Sport Nutr Exerc Metab 2011; 21: 113-123.

39. Cox AJ, Pyne DB, Saunders PU, Fricker PA. Oral administration of the probiotic Lactobacillus fermentum VRI-003 and mucosal immunity in endurance athletes. Br J Sports Med 2010; 44: 222-226. 
40. Gleeson M, Bishop NC, Oliveira M, Tauler PJ. Daily probiotic's (Lactobacillus casei Shirota) reduction of infection incidence in athletes. Int $J$ Sport Nutr Exerc Metab 2011; 21: 55-64.

41. West NP, Pyne DB, Cripps AW, Hopkins WG, Eskesen DC, Jairath A et al. Lactobacillus fermentum (PCC(R)) supplementation and gastrointestinal and respiratory-tract illness symptoms: a randomised control trial in athletes. Nutr $J$ 2011; 10: 30 .

42. Haywood BA, Black KE, Baker D, McGarvey J, Healey P, Brown RC. Probiotic supplementation reduces the duration and incidence of infections but not severity in elite rugby players. J Sci Med Sport 2014; 17: 356-360.

43. Gleeson M. Probiotics. In: Castell LM, Stear S, Burke LM (eds). Nutritional Supplements in Sport, Exercise and Health: An A-Z Guide. Routledge: Abingdon, UK, 2015, pp 214-215.

44. West NP, Horn PL, Pyne DB, Gebski VJ, Lahtinen SJ, Fricker PA et al. Probiotic supplementation for respiratory and gastrointestinal illness symptoms in healthy physically active individuals. Clin Nutr 2014; 33: 581-587.

45. Pyne DB, West NP, Cox AJ, Cripps AW. Probiotics supplementation for athletes - clinical and physiological effects. Eur J Sport Sci 2015; 15: 63-72.

46. Hao Q, Lu Z, Dong BR, Huang CQ, Wu T. Probiotics for preventing acute upper respiratory tract infections. Cochrane Database Syst Rev 2011; 9: CD006895.

47. Bermon S, Petriz B, Kajeniene A, Prestes J, Castell L, Franco OL. The microbiota: an exercise immunology perspective. Exerc Immunol Rev 2015; 21: 70-79.

48. Crooks CV, Wall CR, Cross ML, Rutherfurd-Markwick KJ. The effect of bovine colstrum supplementation on salivary IgA in distance runners. Int J Sport Nutr Exerc Metabol 2006; 16: 47-64.

49. Davison G, Diment BC. Bovine colostrum supplementation attenuates the decrease of salivary lysozyme and enhances the recovery of neutrophil function after prolonged exercise. Br J Nutr 2010;103:1425-1432.

50. Marchbank T, Davison G, Oakes JR, Ghatei MA, Patterson M, Moyer MP et al. The neutriceutical bovine colostrum truncates theincrease in gut permeability caused by heavy exercise in athletes. Am J Gastrointest Liver Physiol 2011; 300: G477-G484.

51. Jones AW, Cameron SJ, Thatcher R, Beecroft MS, Mur LA, Davison G. Effects of bovine colostrum supplementation on upper respiratory illness in active males. Brain Behav Immun 2014; 39: 194-203. 
52. Crooks C, Cross ML, Wall C, Ali A. Effect of bovine colostrum supplementation on respiratory tract mucosal defenses in swimmers. Int J Sport Nutr Exerc Metab 2010; 20: 224-235.

53. Shing CM, Peake JM, Suzuki K, Jenkins DG, Coombes JS. A pilot study: bovine colostrum supplementation and hormonal and autonomic responses to competitive cycling. J Sports Med Phys Fitness 2013; 53: 490-501.

54. Shing CM, Peake J, Suzuki K, Okutsu M, Pereira R, Stevenson L et al. Effects of bovine colostrum supplementation on immune variables in highly trained cyclists. J Appl Physiol 2007; 102: 1113-1122.

55. Brown GD, Gordon S. Fungal beta-glucans and mammalian immunity. Immunity 2003; 19: 311-315.

56. Volman JJ, Ramakers JD, Plat J. Dietary modulation of immune function by $\beta$ glucans. Physiol Behav 2008; 94: 276-284.

57. Davis JM, Murphy EA, Brown AS, Carmichael MD, Ghaffar A, Mayer EP. Effects of oat beta-glucan on innate immunity and infection after exercise stress. Med Sci Sports Exerc 2004; 36: 1321-1327.

58. Nieman DC, Henson DA, McMahon M, Wrieden JL, Davis JM, Murphy EA et al. Beta-glucan, immune function, and upper respiratory tract infections in athletes. Med Sci Sports Exerc 2008; 40: 1463-1471

59. McFarlin BK, Carpenter KC, Davidson T, McFarlin MA. Baker's yeast beta glucan supplementation increases salivary $\lg A$ and decreases cold/flu symptomatic days after intense exercise. J Diet Supp/ 2013; 10: 171-183.

60. Nieman DC. Immunonutrition support for athletes. Nutr Rev 2008; 66: 310320. 
Figure 1: Causes of increased upper respiratory illness symptoms in athletes

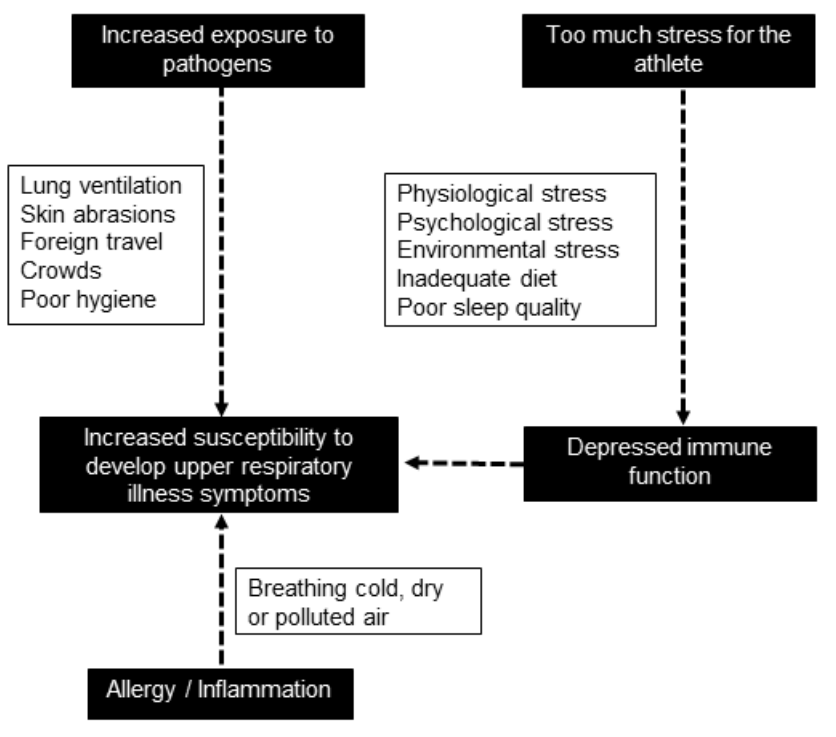


Table 1: Nutrition supplements (listed in alphabetical order) that are claimed to boost immunity and reduce URS incidence in athletes: proposed mechanisms of action and summary of evidence for efficacy. The scientific evidence is indicated with $\bullet \bullet \bullet \bullet$ meaning very strong evidence and 00000 meaning limited to no evidence.

\begin{tabular}{|c|c|c|}
\hline $\begin{array}{l}\text { NUTRITION SUPPLEMENT AND EVIDENCE } \\
\text { RATING }\end{array}$ & PROPOSED MECHANISM OF ACTION & EVIDENCE OF EFFICACY \\
\hline $\begin{array}{l}\beta \text {-glucans } \\
\bullet \bullet \circ \circ \circ\end{array}$ & $\begin{array}{l}\text { Polysaccharides derived from the cell walls of } \\
\text { yeast, fungi and oats that stimulate innate } \\
\text { immunity. }\end{array}$ & $\begin{array}{l}\text { Effective in mice inoculated with influenza } \\
\text { virus but mixed results from human studies for } \\
\text { immune modulation and URS incidence. }\end{array}$ \\
\hline $\begin{array}{l}\text { Bovine colostrum } \\
\bullet \bullet \bullet \circ \bigcirc\end{array}$ & $\begin{array}{l}\text { First milk of the cow that contains antibodies, } \\
\text { growth factors and cytokines. Claimed to boost } \\
\text { mucosal immunity and increase resistance to } \\
\text { infection. }\end{array}$ & $\begin{array}{l}\text { Several studies in athletes that indicate some } \\
\text { immune boosting effects and reduced URS } \\
\text { incidence and duration. }\end{array}$ \\
\hline $\begin{array}{l}\text { Carbohydrate } \\
\bullet \bullet \bullet \circ ০\end{array}$ & $\begin{array}{l}\text { Maintains blood glucose during exercise, } \\
\text { lowers stress hormone and anti-inflammatory } \\
\text { cytokine responses, and thus counters } \\
\text { immune dysfunction. }\end{array}$ & $\begin{array}{l}\text { Ingestion of carbohydrate }(30-60 \mathrm{~g} / \mathrm{h}) \\
\text { attenuates stress hormone and some (but not } \\
\text { all) immune pertubations during exercise but } \\
\text { only very limited evidence that this modifies } \\
\text { infection risk in human athletes. }\end{array}$ \\
\hline $\begin{array}{l}\text { Echinacea } \\
-\infty)^{\prime} \circ{ }^{-}\end{array}$ & $\begin{array}{l}\text { Herbal extract that is a popular supplement } \\
\text { among athletes. Claimed to boost immunity via } \\
\text { stimulatory effects on macrophages and there } \\
\text { is some in vitro evidence for this. }\end{array}$ & $\begin{array}{l}\text { Early human studies indicated possible } \\
\text { beneficial effects but more recent, larger scale } \\
\text { and better controlled studies indicate no effect } \\
\text { of Echinacea on infection incidence or cold } \\
\text { symptom severity. }\end{array}$ \\
\hline $\begin{array}{l}\text { Glutamine } \\
\bullet \circ \circ \circ \circ\end{array}$ & $\begin{array}{l}\text { Nonessential amino acid that is a precursor in } \\
\text { the synthesis of nucleic acids and important for } \\
\text { rapidly dividing cells. Also an important fuel for } \\
\text { immune cells. Plasma concentration of } \\
\text { glutamine falls during prolonged exercise. }\end{array}$ & $\begin{array}{l}\text { Supplementation before and after exercise } \\
\text { does not alter immune perturbations despite } \\
\text { maintenance of plasma glutamine. }\end{array}$ \\
\hline $\begin{array}{l}\text { Kaloba } \\
-\circ \circ \circ \circ\end{array}$ & $\begin{array}{l}\text { Herbal medicine that has been shown to boost } \\
\text { some aspects of immunity in vitro via } \\
\text { stimulatory effects on macrophages. }\end{array}$ & $\begin{array}{l}\text { Evidence from human studies for reduction in } \\
\text { severity and duration of symptoms of sinusitis } \\
\text { and common cold but used as a treatment } \\
\text { rather than as a preventative. }\end{array}$ \\
\hline $\begin{array}{l}\text { N-3 Polyunsaturated fatty acids } \\
\text { } \\
\end{array}$ & Exert anti-inflammatory effects post-exercise. & No evidence in exercising humans. \\
\hline $\begin{array}{l}\text { Probiotics } \\
\bullet \bullet \bullet \circ ०\end{array}$ & $\begin{array}{l}\text { Probiotics are live microorganisms which when } \\
\text { administered orally for several weeks, can } \\
\text { increase the numbers of beneficial bacteria in } \\
\text { the gut. This has been associated with a range } \\
\text { of potential benefits to gut health, as well as } \\
\text { modulation of immune function. }\end{array}$ & $\begin{array}{l}\text { Human studies show improvements in some } \\
\text { aspects of acquired immunity and reduced } \\
\text { incidence of URS and gastrointestinal } \\
\text { problems. }\end{array}$ \\
\hline $\begin{array}{l}\text { Quercetin } \\
\bullet \bullet \bullet \circ ०\end{array}$ & $\begin{array}{l}\text { A plant flavonoid; in vitro studies show strong } \\
\text { anti-inflammatory, anti-oxidative, and anti- } \\
\text { pathogenic effects. Animal data indicate } \\
\text { increase in mitochondrial biogenesis and } \\
\text { endurance performance. }\end{array}$ & $\begin{array}{l}\text { Human studies show some reduction in URS } \\
\text { incidence during short periods of intensified } \\
\text { training and mild stimulation of mitochondrial } \\
\text { biogenesis and endurance performance in } \\
\text { untrained subjects. }\end{array}$ \\
\hline $\begin{array}{l}\text { Quercetin with epigallocatechin gallate } \\
\bullet \bullet \bullet \circ \bigcirc\end{array}$ & $\begin{array}{l}\text { Flavonoid mixture promotes anti-inflammatory } \\
\text { and anti-oxidative effects, and immune } \\
\text { function improvement, above that of quercetin } \\
\text { alone. }\end{array}$ & $\begin{array}{l}\text { Human study showed strong anti-inflammatory } \\
\text { effect, with modest anti-oxidative effect and } \\
\text { improvement in innate immunity but no data on } \\
\text { URS incidence. }\end{array}$ \\
\hline $\begin{array}{l}\text { Vitamin C } \\
\bullet \bullet \circ \circ ০\end{array}$ & $\begin{array}{l}\text { An essential water-soluble antioxidant vitamin } \\
\text { that quenches reactive oxygen species and } \\
\text { augments immunity. Reduces interleukin-6 } \\
\text { and cortisol responses to exercise in humans. }\end{array}$ & $\begin{array}{l}\text { Relatively small effects on cortisol compared } \\
\text { with carbohydrate; immune measures no } \\
\text { different from placebo. Some evidence of } \\
\text { efficacy in reducing URS incidence after } \\
\text { ultramarathon events. }\end{array}$ \\
\hline $\begin{array}{l}\text { Vitamin D } \\
\bullet \bullet \bullet \bullet \circ\end{array}$ & $\begin{array}{l}\text { Fat soluble vitamin that is mostly produced via } \\
\text { the action of sunlight in the skin. Induces } \\
\text { production of antimicrobial proteins, enhances } \\
\text { natural killer cell cytolytic activity, increases } \\
\text { the generation of reactive oxygen species in } \\
\text { phagocytic cells, augments macrophage } \\
\text { interleukin-1 } \beta \text { secretion and upregulates the } \\
\text { expression of CD14, the lipopolysaccharide } \\
\text { receptor. }\end{array}$ & $\begin{array}{l}\text { Low vitamin D status is associated with low } \\
\text { saliva immunoglobulin A secretion, low pro- } \\
\text { inflammatory cytokine production by antigen- } \\
\text { stimulated mononuclear cells and increased } \\
\text { respiratory infection risk with longer lasting } \\
\text { illness symptoms. Oral vitamin D3 } \\
\text { supplements of around } 4,000 \text { IU/day can } \\
\text { reduce URS incidence. }\end{array}$ \\
\hline $\begin{array}{l}\text { Vitamin E } \\
\bullet \circ ০ ০ ০\end{array}$ & $\begin{array}{l}\text { An essential fat-soluble antioxidant vitamin } \\
\text { that quenches exercise-induced reactive } \\
\text { oxygen species and augments immunity. Good } \\
\text { evidence for some immune boosting effects in } \\
\text { the frail elderly. }\end{array}$ & $\begin{array}{l}\text { No evidence of similar benefit for younger } \\
\text { healthy humans or athletes. }\end{array}$ \\
\hline $\begin{array}{l}\text { Zinc } \\
\bullet \circ \circ ০ \circ\end{array}$ & $\begin{array}{l}\text { Zinc deficiency results in impaired immunity } \\
\text { and zinc deficiency is not uncommon in } \\
\text { athletes. An essential mineral that is claimed } \\
\text { to reduce incidence and duration of colds. }\end{array}$ & $\begin{array}{l}\text { No evidence for reduced infection incidence } \\
\text { with zinc supplementation in adult humans. } \\
\text { Some (but not all) human studies suggest a } \\
\text { reduction in duration of cold symptoms if zinc } \\
\text { gluconate lozenges are administered within } 24 \\
\mathrm{~h} \text { of cold symptom onset. Unlikely to be of any } \\
\text { real benefit to athletes unless they are zinc } \\
\text { deficient. }\end{array}$ \\
\hline
\end{tabular}

